\title{
Fatty Acid Composition in Intramuscular Lipids of Experimental Scaly Crossbreds in 3-Year-Old Common Carp (Cyprinus carpio L.)
}

\author{
H. BUCHTOVÁ ${ }^{1}$, Z. SVOBODOVÁ ${ }^{1,2}$, M. KŘÍŽEK ${ }^{3}$, F. VÁCHA ${ }^{2,3}$, M. KOCOUR ${ }^{2}$, J. VELÍŠEK $^{2}$ \\ ${ }^{1}$ Department of Meat Hygiene and Technology, Faculty of Veterinary Hygiene and Ecology, University of \\ Veterinary and Pharmaceutical Sciences, Brno, Czech Republic \\ ${ }^{2}$ University of South Bohemia, České Budějovice, Research Institute of Fish Culture and \\ Hydrobiology, Vodňany, Czech Republic \\ ${ }^{3}$ University of South Bohemia, Agricultural Faculty, České Budějovice, Czech Republic
}

Received April 26, 2007

Accepted October 2, 2007

\begin{abstract}
Buchtová H., Z. Svobodová, M. Křŕžek, F. Vácha, M. Kocour, J. Velíšek: Fatty Acid Composition in Intramuscular Lipids of Experimental Scaly Crossbreds in 3-Year-Old Common Carp (Cyprinus carpio L.). Acta Vet. Brno 2007, 76: S73-S81.
\end{abstract}

The aim of the study was to determine the differences in the composition of fatty acids (in \% of total fatty acids investigated), their total contents and ratios (n-6/n-3) in intramuscular lipids (IML) of three experimental scaly groups of carp (pure line PS: Přerov scaly carp, hybrid PS $\times$ M72: Přerov scaly carp $\times$ Northern mirror carp, hybrid PS $\times$ ROP: Přerov scaly carp $\times$ Ropsha scaly carp) in comparison with the mirror carp control group (hybrid M2 $\times$ M72: Hungarian mirror carp $\times$ Northern mirror carp). Compared with the controls $(\mathrm{M} 2 \times \mathrm{M} 72)$, fat content in meat of experimental groups of carp (PS, PS $\times$ M72, PS $\times$ ROP) was practically the same $(p>0.05)$. The highest fat content $\left(89.8 \pm 1.94 \mathrm{~g} \cdot \mathrm{kg}^{-1}\right)$ was found in meat of PS $\times$ ROP hybrids. Composition of fatty acids in IML was not influenced to any large degree by a hybrid type or by gender. The only exception was the IML of PS $\times$ ROP hybrids which, compared with controls $(\mathrm{M} 2 \times$ M72) and PS $\times$ M72 hybrids, contained significantly $(p<0.05)$ more polyunsaturated fatty acids $\left(\right.$ PUFA $\left._{\text {sum }}\right)$. Higher content of oleic acid (PS $\times$ ROP: $54.94 \pm 0.70 \%$ ) in carp fat was manifested by higher monounsaturated fatty acids (MUFA ${ }_{\text {sum }}$ ) values (PS $\times$ ROP: $64.20 \pm 0.57 \%$ ). IML of PS $\times$ ROP hybrids contained $6.99 \pm 0.20 \%$ of linoleic acid and $0.53 \pm 0.02 \%$ of arachidonic acid. Contents of $\alpha$-linoleic acid (PS $\times$ ROP: $0.86 \pm 0.09 \%$ ), eicosapentaenoic acid (EPA) (PS x ROP: $0.69 \pm$ $0.09 \%)$ and docosahexaenoic acid (DHA) $(\mathrm{PS} \times \mathrm{ROP}: 0.35 \pm 0.02 \%)$ were low and influenced the PUFA n-6/n-3 ratio (PS $\times$ ROP: $3.25 \pm 0.18$ ). From this point of view, the IML of carp groups in this experiment constituted a relatively minor source of PUFA $_{n-3}(\mathrm{PS} \times \mathrm{ROP}: 2.39 \pm 0.09 \%)$.

Carp, polyunsaturated fatty acid, $\alpha$-linolenic acid, eicosapentaenoic acid, docosahexaenoic acid, n-6/n-3 PUFA ratio

Lipids are among the most variable muscle tissue components in fish. Their contents and compositions in the body may be influenced by a number of factors (species of fish, health status, motoric activity, age, sexual cycle stage, type of rearing and of stock composition, trophic relations - interaction, water temperature, type of diet and its composition, feeding intensity, type of digestion, etc.).

From the human nutrition point of view, the most important group is polyunsaturated fatty acids (PUFA ${ }_{n-3}$ ) (Anonymous 1994). Sufficient quantities of PUFA ${ }_{n-3}$ sum. fatty acids in human nutrition, and especially the presence of the essential $\alpha$-linolenic acid (C18:3n3 ), eicosapentaenic acid (EPA) (C20:5n-3) and docosahexaenic acid (DHA) (C22:6n-3), have a positive effect on human health (Steffens 1997). An excess of PUFA ${ }_{n-6}$, on the

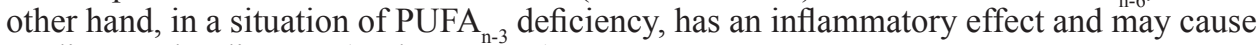
cardiovascular diseases (Colette 2001).

Qualitative and quantitative composition of fatty acids (and PUFA in particular) in fish diet affects fatty acid composition in lipids contained in body tissues. Abundance of natural

Address for correspondence:

MVDr. Hana Buchtová, Ph.D.

University of Veterinary and Pharmaceutical Sciences Brno

Department of Meat Hygiene and Technology

Palackého 1-3

61242 Brno, Czech Republic

Fax: +420541321230

E-mail: buchtovah@vfu.cz

http://www.vfu.cz/acta-vet/actavet.htm 
diet (marine phytoplankton) with their high EPA and DHA contents increases PUFA levels in muscle tissue of marine fish. In contrast, natural diet of freshwater fish (freshwater algae, crustacea, aquatic larvae of insects) contains predominantly PUFA with 18 carbon chains (Csengeri 1996; Steffens 1997).

The freshwater fish reared in ponds grow faster in comparison with fish from natural waters (unfed) because of better living conditions and more intensive management. The amount of natural food they consume is limited, and varies according to the specific situation in their habitat. Fish food needs to be supplemented, and the basic supplement is cereals, which are rich primarily in saccharides. The primary product of desaturation of saturated fatty acid (SFA) syntethised primarily from starch-rich diet is oleic acid (C18:1n-9), which contributes to an increase in monounsaturated fatty acid (MUFA) content (Henderson 1996). At the same time, PUFA decreases linearly. The decrease is more intensive in fastergrowing fish with a higher final weight (Geri et al. 1995).

The carp monitored in our experiment were given saccharide-rich feed (in addition to natural feed, carp fry was fed sieved wheat meal and, starting from the second year, whole wheat was used, and certain changes in lipid structure may therefore be expected. This assumption is particularly true about a Přerov scaly carp and Ropsha scaly hybrid (PS $\times$ ROP), in which growth and dressing out parameters were demonstrated (Buchtová et al. 2006ab). Compared with the other experimental groups, this hybrid demonstrated the best growth parameters, and proved the most promising for commercial aquaculture. Excellent results of growth tests in the PS x ROP hybrid should not, however, be accompanied with lower PUFA content in lipids as a result of the feed given to them (wheat).

The aim of the present study was to determine the differences in the composition of fatty acids, and their total and relative quantities (PUFA ratio) in intramuscular lipids (IML) of three experimental groups of carp, i.e. a pure line of Přerov scaly carp (PS), a hybrid line of Přerov scaly carp and Northern mirror carp (PS $\times$ M72) and a hybrid line of Přerov scaly carp and Ropsha scaly carp $(\mathrm{PS} \times \mathrm{ROP})$ in comparison with the quality of control hybrids of Hungarian and Northern mirror carp $(\mathrm{M} 2 \times \mathrm{M} 72)$ in harvest size $\left(\mathrm{K}_{3}\right)$. The secondary aim of the study was to find whether there were any statistically significant differences in lipid composition between sexes (i.e. female v. male carp) in individual groups.

The study is a part of a comprehensive assessment of the tested carp hybrids, and it complements papers published by Buchtová et al. (2006ab) and (Buchtová et al. 2007).

\section{Materials and Methods}

Performance tests of scaly phenotypes of the common carp were started in 2001 by the fish farming company Rybníkářství Pohořelice. In the experiments, Přerov scaly carps (PS) were used at the maternal position. The PS were crossed with males of other carp breeds (top crossing) namely the Přerov scaly carp (PS) for the production of a pure line, Ropsha scaly carp (ROP) and Northern mirror carp (M72). The mirror carp hybrid of the Hungarian and the Northern mirror carp (M2 $\times$ M72) were used as controls. The establishment of test populations and the test protocol were designed according to Linhart et al. (2002).

In the first test year, fry of each experimental group were stocked separately into two ponds (6 ponds in total, 0.06 ha each) together with its control group $(\mathrm{M} 2 \times \mathrm{M} 72)$ of different scaliness.

The stocking density was 20000 fish per 0.06 ha. At advanced fry stage (after 6 weeks), the carp were fished out, checked for weight and the stocking density was reduced to 1600 fish per 0.06 ha. Because natural diet was abundant, the fry were only fed limited amounts of sieved wheat meal and, exceptionally, carp feed mixture pellets (KP1). The next growth and survival check was made at the end of the vegetation period before the carp were transferred to special wintering tanks (2001).

From 2002 onward, the fish were group marked (different cut of an abdominal fin) and kept in mixed stocks in three ponds: (2 $700 \mathrm{carp} / 1.27 \mathrm{ha}$ ), (3 $400 \mathrm{carp} / 1.60 \mathrm{ha}$ ) and (2 $400 \mathrm{carp} / 1.13 \mathrm{ha}$ ). Two-year old grass carp were introduced in all ponds (150 grass carp per pond) to control macrophytes. For additional feeding of the fish tested, uncrushed whole wheat was used. Checks of fish weight and survival checks were made before and after each wintering period.

The performance assessment of dressing out parameters was made at the end of the 2003 vegetation period for $\mathrm{K}_{3}$ (harvest size) from all three fishponds (258 carp in total). A total of 15, 14 and 35 carp of each group were randomly selected from fishponds. 
Laboratory tests of fatty acids composition were made in 20 carp of each line $(10 q+10 \hat{\jmath})$ from the pond Jaroslav, i.e. in 80 carp in total. Fish from that pond scored best results in efficiency tests (Buchtová et al. 2006a).

Sample preparation

Immediately after slaughter (a standard manner in the Mušov Freshwater Fish Processing Plant of the Rybníkářství Pohořelice Comp.) fish were filleted. An aliquot $(50 \mathrm{~g})$ of the each sample (middle part of the fillet) was used for fat determinations. Content of fat was determined quantitatively by extraction in diluents using Soxtec semiautomatic system (Tecator, Sweden) with method following recommendation of the producer (AN 67/83). The remaining middle part of the each fillet was put into the dark glass powder bottles, frozen and stored at $-18{ }^{\circ} \mathrm{C}$ until fatty acid analyses. The determination of fatty acids composition was performed by gas chromatography using HP 4890 apparatus with flame ionization detector (FID) and capillary column Omega Wax TM250 $(30 \mathrm{~m} \times 0.25 \mathrm{~mm} \times 0.25 \mu \mathrm{m})$. The optimum temperature gradient was $140{ }^{\circ} \mathrm{C}$ to $240{ }^{\circ} \mathrm{C}\left(5^{\circ} \mathrm{C} / \mathrm{min}\right)$. The injector temperature was $280^{\circ} \mathrm{C}$, the FID temperature was $300^{\circ} \mathrm{C}$. Nitrogen was used as the carrier gas.

Basic statistical values (means, S.D.) of the parameters investigated were processed in Excel 97. Statistical significance was evaluated using the multifactorial analysis of variance (ANOVA, Statgraphics 6.0).

\section{Results}

Fatty acid composition (in \% of total determined fatty acids) including SFA sum $_{\text {, MUFA }}$, PUFA $_{\text {sum }}$ and the n-6/n-3 PUFA ratio in intramuscular lipids and content of fat in fillets of experimental scaly carp (PS, PS $\times$ M72, PS $\times$ ROP) compared with controls $(\mathrm{M} 2 \times$ M72) are given in Table 1 .

The fat content of muscle tissues (fillets) of the control group of mirror carp (M2 $\times$ M72) and of the experimental scaly carp (PS, PS $\times$ M72, PS $\times$ ROP) was practically identical. In experimental carp (PS, PS $\times$ M72, PS $\times$ ROP) significant $(p<0.05)$ differences in muscle fat content were found. Most fat $\left(89.8 \pm 1.94 \mathrm{~g} \cdot \mathrm{kg}^{-1}\right)$ was contained in muscle tissues of PS $\times$ ROP hybrids.

Levels of individual fatty acids (FA) including their sums (SFA sum $_{\text {MUFA }}$ and PUFA $\left._{\text {sum }}\right)$ were practically identical in all the groups of carp studied $(\mathrm{M} 2 \times \mathrm{M} 72, \mathrm{PS}, \mathrm{PS} \times$ M72, PS $\times$ ROP). Statistically significant differences were found in PUFA sum $_{\text {sulues. Their }}$ content in IML of PS $\times$ ROP scaly hybrids was significantly higher $(p<0.05)$ compared with mirror carp controls $(\mathrm{M} 2 \times \mathrm{M} 72)$ and PS $\times$ M72 scaly hybrids.

Lipids of all groups of carp were composed predominantly of MUFA sum $_{\text {. The most }}$ abundant in carp intramuscular lipids was oleic acid (C18:1). Also plentiful were palmitic acid (C16 : 0), palmitooleic acid (C16:1), linolic acid (C18:2n-6) and gadoleic acid (C20:1n-9). The content of all other FA, with the exception of myristoic acid (C14:0) and stearic acid (C18:0), was below 1\%.

The most abundant in PUFA $_{n-3 \text { sum }}$ group was $\alpha$-linoleic fatty acid (C18 : 3n-3). Also present there were eicosapentaenoic acid (EPA) (C20:5n-3) and docosahexaenoic acid (DHA) (C22: 6n-3).

The n-6/n-3 PUFA ratio showed no statistically significant differences between the groups of carp studied. The n-6/n-3 PUFA ratio from the minimum value $3.14 \pm 0.24$ (PS) to maximum value $3.47 \pm 0.15(\mathrm{M} 2 \times \mathrm{M} 72)$ was found.

Fatty acid composition (in \% of total determined fatty acids) including the levels of $\mathrm{SFA}_{\text {sum }}, \mathrm{MUFA}_{\text {sum }}, \mathrm{PUFA}_{\text {sum }}$ and the n-6/n-3 PUFA ratio in muscle tissue of experimental scaly carp $(\mathrm{PS}, \mathrm{PS} \times \mathrm{M} 72, \mathrm{PS} \times \mathrm{ROP})$ compared with controls $(\mathrm{M} 2 \times \mathrm{M} 72)$ in relation to sex are given in Table 2.

The fat content of muscle tissues (fillets) of the male and female carp (M2 $\times$ M72, $\mathrm{PS} \times \mathrm{M} 72, \mathrm{PS} \times \mathrm{ROP}$ ) was practically identical. Only in experimental carp (PS) significant $(p<0.05)$ differences in muscle fat content in relation to sex were found.

Statistically significant differences in the composition of intramuscular lipids of female and male carp studied were ascertained in six cases. Compared with mirror carp female controls (M2 $\times$ M72), lipids of their male counterparts contained greater $(p<0.01)$ amounts of PUFA ${ }_{\mathrm{n}-6 \mathrm{~s} u m}$ and, consequently, greater $(p<0.05)$ amounts of PUFA sum. $_{\text {. Compared with }}$ 
Table 1. Fatty acid composition (in \% of total fatty acids investigated) and n-6/n-3 PUFA ratio in intramuscular lipids of control group (M2 $\times$ M72) and experimental scaly groups (PS, PS $\times$ M72, PS $\times$ ROP) of the common carp (Cyprinus carpio, Linnaeus 1758). Multiple range test of analysis of variance. Groups with different alphabetic superscript in lines differ significantly at $p<0.05$.

\begin{tabular}{|c|c|c|c|c|}
\hline Index & $\begin{array}{l}\text { M2 } \times \text { M72 } n \\
\text { Mean } \pm \text { S.D. } 20\end{array}$ & $\begin{array}{l}\text { PS } \\
\text { Mean } \pm \text { S.D. } 20\end{array}$ & $\begin{array}{l}\text { PS } \times \text { M72 } n \\
\text { Mean } \pm \text { S.D. } 20\end{array}$ & $\begin{array}{l}\text { PS } \times \text { ROP } n \\
\text { Mean } \pm \text { S.D. } 20\end{array}$ \\
\hline Fat $\quad \mathrm{g} \cdot \mathrm{kg}^{-1}$ & $70.2 \pm 1.95 \mathrm{ab}$ & $54.4 \pm 1.96^{\mathrm{a}}$ & $55.5 \pm 1.23^{a}$ & $89.8 \pm 1.94^{b}$ \\
\hline C14:0 & $1.04 \pm 0.09^{a}$ & $1.25 \pm 0.17^{\mathrm{a}}$ & $1.07 \pm 0.03^{\mathrm{a}}$ & $1.16 \pm 0.05^{\mathrm{a}}$ \\
\hline C16:0 & $18.80 \pm 0.49^{\mathrm{a}}$ & $18.60 \pm 0.21^{\mathrm{a}}$ & $18.98 \pm 0.02^{a}$ & $18.84 \pm 0.35^{\mathrm{a}}$ \\
\hline C18:0 & $1.57 \pm 0.26^{\mathrm{a}}$ & $1.30 \pm 0.13^{a}$ & $1.46 \pm 0.24^{\mathrm{a}}$ & $1.30 \pm 0.15^{\mathrm{a}}$ \\
\hline $\mathrm{C} 20: 0$ & $0.05 \pm 0.01^{\mathrm{a}}$ & $0.15 \pm 0.25^{\mathrm{a}}$ & $0.17 \pm 0.24^{\mathrm{a}}$ & $0.07 \pm 0.01^{\mathrm{a}}$ \\
\hline SFA $_{\text {sum }}$ & $21.46 \pm 0.62^{a}$ & $21.31 \pm 0.48^{\mathrm{a}}$ & $21.68 \pm 0.47^{a}$ & $21.37 \pm 0.46^{\mathrm{a}}$ \\
\hline C16:1 & $9.22 \pm 0.47^{\mathrm{a}}$ & $9.22 \pm 0.26^{\mathrm{a}}$ & $8.75 \pm 0.46^{\mathrm{a}}$ & $9.26 \pm 0.46^{\mathrm{a}}$ \\
\hline C18:1 & $55.23 \pm 0.64^{\mathrm{a}}$ & $55.46 \pm 0.16^{\mathrm{a}}$ & $55.66 \pm 0.41^{a}$ & $54.94 \pm 0.70^{\text {a }}$ \\
\hline MUFA $_{\text {sum }}$ & $64.45 \pm 0.61^{a}$ & $64.68 \pm 0.14^{\mathrm{a}}$ & $64.41 \pm 0.37^{a}$ & $64.20 \pm 0.57^{a}$ \\
\hline $\mathrm{C} 18: 3 n 3$ & $0.77 \pm 0.09^{\mathrm{a}}$ & $0.84 \pm 0.10^{\mathrm{a}}$ & $0.79 \pm 0.09^{\mathrm{a}}$ & $0.86 \pm 0.09^{\mathrm{a}}$ \\
\hline C18:4n3 & $0.20 \pm 0.02^{\mathrm{a}}$ & $0.20 \pm 0.01^{\mathrm{a}}$ & $0.20 \pm 0.01^{\mathrm{a}}$ & $0.22 \pm 0.01^{\mathrm{a}}$ \\
\hline $\mathrm{C} 20: 4 \mathrm{n} 3$ & $0.08 \pm 0.01^{\mathrm{a}}$ & $0.10 \pm 0.01^{\mathrm{a}}$ & $0.08 \pm 0.01^{\mathrm{a}}$ & $0.09 \pm 0.01^{\mathrm{a}}$ \\
\hline $\mathrm{C} 20: 5 \mathrm{n} 3$ & $0.58 \pm 0.06^{\mathrm{a}}$ & $0.69 \pm 0.15^{\mathrm{a}}$ & $0.65 \pm 0.21^{\mathrm{a}}$ & $0.69 \pm 0.09^{\mathrm{a}}$ \\
\hline $\mathrm{C} 21: 5 \mathrm{n} 3$ & $0.03 \pm 0.0^{\mathrm{a}}$ & $0.04 \pm 0.0^{\mathrm{a}}$ & $0.04 \pm 0.01^{\mathrm{a}}$ & $0.04 \pm 0.0^{\mathrm{a}}$ \\
\hline $\mathrm{C} 22: 5 \mathrm{n} 3$ & $0.14 \pm 0.02^{\text {a }}$ & $0.14 \pm 0.01^{\mathrm{a}}$ & $0.16 \pm 0.06^{\mathrm{a}}$ & $0.15 \pm 0.03^{\mathrm{a}}$ \\
\hline $\mathrm{C} 22: 6 \mathrm{n} 3$ & $0.34 \pm 0.02^{\mathrm{a}}$ & $0.39 \pm 0.04^{\mathrm{a}}$ & $0.33 \pm 0.03^{\mathrm{a}}$ & $0.35 \pm 0.02^{\mathrm{a}}$ \\
\hline PUFA n $3_{\text {sum }}$ & $2.14 \pm 0.16^{\mathrm{a}}$ & $2.40 \pm 0.13^{a}$ & $2.24 \pm 0.19^{a}$ & $2.39 \pm 0.09^{\mathrm{a}}$ \\
\hline $\mathrm{C} 16: 2 \mathrm{n} 4$ & $0.13 \pm 0.02^{\mathrm{a}}$ & $0.14 \pm 0.01^{\mathrm{a}}$ & $0.13 \pm 0.01^{\mathrm{a}}$ & $0.16 \pm 0.03^{\mathrm{a}}$ \\
\hline C16:3n4 & $0.18 \pm 0.01^{\mathrm{a}}$ & $0.20 \pm 0.03^{\mathrm{a}}$ & $0.17 \pm 0.02^{\mathrm{a}}$ & $0.18 \pm 0.03^{\mathrm{a}}$ \\
\hline $\mathrm{C} 22: 4 \mathrm{n} 4$ & $0.10 \pm 0.01^{\mathrm{a}}$ & $0.12 \pm 0.01^{\mathrm{a}}$ & $0.09 \pm 0.03^{\mathrm{a}}$ & $0.11 \pm 0.01^{\mathrm{a}}$ \\
\hline $\mathrm{PUFA} \mathrm{n}_{\text {sum }}$ & $0.41 \pm 0.02^{\mathrm{a}}$ & $0.46 \pm 0.04^{a}$ & $0.40 \pm 0.05^{\mathrm{a}}$ & $0.45 \pm 0.05^{\mathrm{a}}$ \\
\hline C18:2n6 & $6.69 \pm 0.31^{\mathrm{a}}$ & $6.70 \pm 0.13^{\mathrm{a}}$ & $6.58 \pm 0.26^{\mathrm{a}}$ & $6.99 \pm 0.20^{\mathrm{a}}$ \\
\hline C18:3n6 & $0.16 \pm 0.02^{\mathrm{a}}$ & $0.17 \pm 0.01^{\mathrm{a}}$ & $0.16 \pm 0.01^{\mathrm{a}}$ & $0.17 \pm 0.02^{\mathrm{a}}$ \\
\hline $\mathrm{C} 20: 4 \mathrm{n} 6$ & $0.50 \pm 0.03^{\mathrm{a}}$ & $0.56 \pm 0.02^{\mathrm{a}}$ & $0.50 \pm 0.02^{\mathrm{a}}$ & $0.53 \pm 0.02^{\mathrm{a}}$ \\
\hline $\mathrm{C} 22: 5 \mathrm{n} 6$ & $0.07 \pm 0.01^{\mathrm{a}}$ & $0.07 \pm 0.01^{\mathrm{a}}$ & $0.06 \pm 0.01^{\mathrm{a}}$ & $0.07 \pm 0.01^{\mathrm{a}}$ \\
\hline PUFA n6 ${ }_{\text {sum }}$ & $7.42 \pm 0.32^{\mathrm{a}}$ & $7.50 \pm 0.15^{\mathrm{a}}$ & $7.30 \pm 0.27^{\mathrm{a}}$ & $7.76 \pm 0.20^{a}$ \\
\hline C20:1n9 & $3.90 \pm 0.20^{\mathrm{a}}$ & $3.88 \pm 0.11^{\mathrm{a}}$ & $4.04 \pm 0.11^{\mathrm{a}}$ & $3.40 \pm 0.20^{\mathrm{a}}$ \\
\hline PUFA n9 & $3.90 \pm 0.20^{\mathrm{a}}$ & $3.88 \pm 0.11^{\mathrm{a}}$ & $4.04 \pm 0.11^{\mathrm{a}}$ & $3.40 \pm 0.20^{\mathrm{a}}$ \\
\hline PUFA $_{\text {sum }}$ & $13.87 \pm 0.50^{\mathrm{a}}$ & $14.23 \pm 0.16^{\mathrm{ab}}$ & $13.98 \pm 0.42^{\mathrm{a}}$ & $14.56 \pm 0.34^{b}$ \\
\hline Ratio $_{n-6 / n-3}$ & $3.47 \pm 0.15^{a}$ & $3.14 \pm 0.24^{\mathrm{a}}$ & $3.28 \pm 0.32^{a}$ & $3.25 \pm 0.18^{\mathrm{a}}$ \\
\hline
\end{tabular}

M2 - Hungarian Mirror Carp, M72 - Northern Mirror Carp, PS - Přerov Scaly Carp, ROP - Ropsha Scaly Carp

females of the pure hybrid line (PS), lipids of their male counterparts contained greater $(p$ $<0.05)$ amounts of myristic acid $(\mathrm{C} 14: 0)$ and greater $(p<0.01)$ amounts of DHA $(\mathrm{C} 22$ : $6 n-3)$. Lipids of scaly hybrid female carp (PS $\times$ M72) were found to contain significantly $(p<0.05)$ more docosapentaenoic acid $(\mathrm{C} 22: 5 n-3)$ as compared to male. Lipids of scaly hybrid male carp (PS $\times$ ROP) contained greater $(p<0.01)$ amounts of PUFA ${ }_{\mathrm{n}-6 \text { sum }}$ than the female counter parts. Contents of other FA studied were practically identical in all the carp groups investigated. 


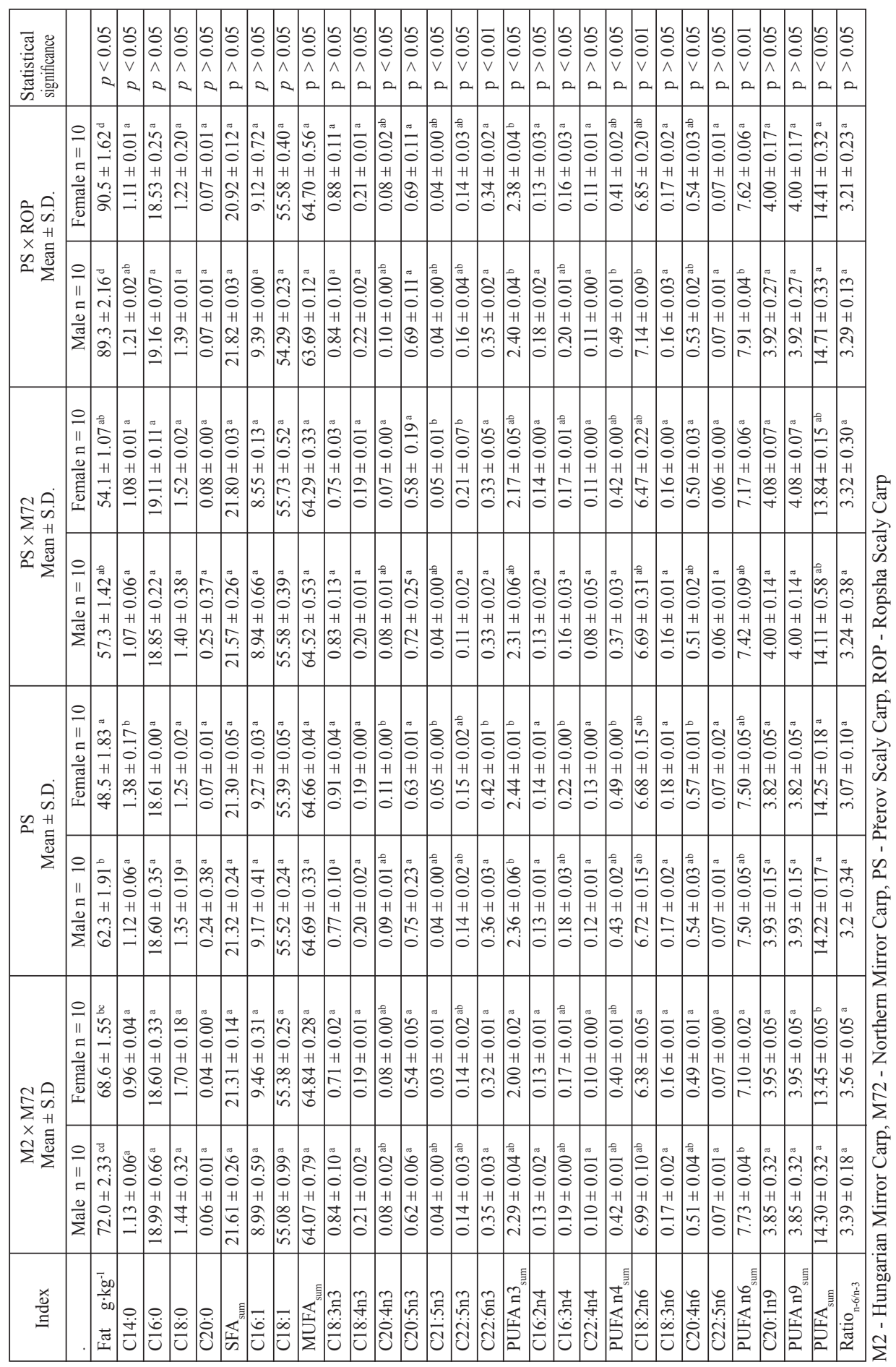


Table 2. Fatty acid composition (in $\%$ of total fatty acids investigated) and n-6/n-3 PUFA ratio in intramuscular lipids in relation to sex (male vs. female) of the control group $(\mathrm{M} 2 \times \mathrm{M} 72)$ and experimental scaly groups (PS, PS $\times$ M72, PS $\times$ ROP) of the common carp (Cyprinus carpio, Linnaeus 1758). Multiple range test of analysis of variance. Groups with different alphabetic superscript in lines differ significantly at the given significance.

The n-6/n-3 PUFA ratio showed no statistically significant differences between the groups of carp studied.

\section{Discussion}

From the human health point of view (prevention of cardiovascular and tumour diseases), much attention in evaluations is paid especially to the presence of essential fatty acids (C18 : 1n-9, C18 : 2n-6, C18 : 3n-3) and their metabolites (C20:4n-6, C22 : 5n-3, C22 : 6n-3). Okuyama et al. (1997), who investigated fatty acid metabolism in mammals (and in man in particular) in their study, believe that the most important from the point of view of the prevention and occurrence of certain chronic diseases is the evaluation of the $n-6 / n-$ 3 PUFA ratio. They concluded that excess linoleic acid (C18:2n-6) and elevated n-6/n-3 PUFA ratio in tissues result in over- and unbalanced production of lipid mediators related to arachidonic acid (C20:4n-6). This situation leads to enhanced ischemic/inflammatory tendencies, thereby increasing the incidence of chronic diseases. Therefore, Okuyama et al. (1997) recommended that the n-6/n-3 PUFA ratio be $\leq 2$. The same PUFA ratio in fish has also been evaluated in the studies by Fajmonová et al. (2003) and Komprda et al. (2005). Other authors monitoring fatty acid profiles (in \% of total determined fatty acids or in $\mathrm{g} \cdot \mathrm{kg}^{-1}$ tissue) in fish (Steffens 1997, Rasoarahona et al. 2004) propose that their reverse ratio (n-3/n-6 PUFA ratio) be used in evaluating FA presence. According to this author, the lipids beneficial to human health are those whose composition corresponds to the n-3/n-6 PUFA ratio of 1 to 5 (freshwater fish) or 5 to 10 (sea fish).

Comments on the results of our experiment will be made in line with this approach to fatty acid evaluation. To facilitate a comparison between our results and results of other authors, fatty acid values are reported only in \% (of total fatty acids investigated).

The fat of carp monitored in this study was composed primarily of MUFA $_{\text {sum }}$ (PS $\times$ ROP: $64.20 \pm 0.57 \%$ ), with the oleic acid C18 : 1n-9 (PS $\times$ ROP: $54.94 \pm 0.70 \%$ ) being the dominant acid. The same fatty acid composition in carp fed with wheat has also been used in the studies of Steffens (1997) and Fajmonová et al. (2005). However, the C18:1n9 acid and MUFA amounts in total lipids ascertained in their experiments were smaller

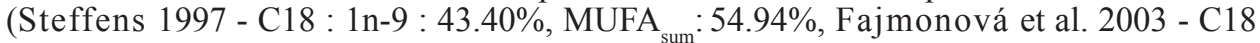
$: 1 n-9: 45.97 \pm 0.26 \%$ MUFA $_{\text {sum }}: 58.97 \pm 0.25 \%$ ). On the other hand Rasoarahona et al. (2004) who monitored in their experiment the FA profile in carp (without feeding) over the whole year found significantly smaller amounts of C18 : 1n-9 (from Itasy Lake, Madagascar: $17.1 \pm 0.80 \%$ October). Even smaller amounts of C18 : 1n-9 (14.8\%) in carp lipids (from natural waters, unfed) have been reported by Steffens (1997). The reason is a very low level of C18 : 1n-9 (zooplankton $11.2 \%$, chironomid larvae $7.2 \%$ ) in the natural carp diet (Csengeri et al. 1978). Oleic acid content in wheat (11.2\%) is also low (Steffens et al. 1998). Wheat, however, is rich in glycides. Oleic acid is produced by desaturation of saturated FA synthesized in the carp organism from this energy-rich feed (Csengeri 1996; Henderson 1996).

Linoleic acid (C18 : 2n-6) content in the IML of carp investigated in our study (PS $\times$ ROP: $6.99 \pm 0.20 \%$ ) did not differ from linolic acid values published by some other authors, e.g. Rasoarahona et al. (2004) (unfed carp from Itasy Lake, Madagascar: $10.6 \pm 1.16 \%$ October) or Fajmonová et al. (2003) (carp fed with wheat: $6.91 \pm 0.12 \%$ ). Levels of this FA in the natural diet (zooplankton 4.8\%, chironomid larvae 8.9\%) and the prepared feed (wheat $70.4 \%$ ) are very different (Steffens et al. 1998). It follows from our experiment that high linolic acid levels in wheat do nothing to increase its concentrations in carp IML. 
More recent studies (Komprda et al. 2005) prefer to evaluate arachidonic acid (C20 : $4 \mathrm{n}-6$ ), which is a linoleic acid metabolite. Eicosanoids (prostaglandins, thrombaxanes and leucotrienes), which are produced from arachidonic acid (C20:4n-6), negatively influence human health because they increase the risk of cardiovascular diseases and immune system diseases (proinflammatory and proaggregatory properties). C20 : 4n-6 levels in carp IML in our experiment were very low (PS $\times$ ROP: $0.53 \pm 0.02 \%$ ) and they were comparable with data (carp: $1.0 \pm 0.0 \%$ ) published by Komprda et al. (2005), who monitored the effect of diets of different composition on the FA spectrum in white meat (in chicken, turkey, carp and trout meat). The authors greatly emphasized the evaluation of the levels of the socalled long-chain n-3 polyunsaturated fatty acid. Fatty acids belonging to this group (C18 : 3n-3, EPA, DHA) and their derivates, the eicosanoids (prostacyclines), play a very positive role in the prevention of lifestyle diseases (atherosclerosis, hypertension, coronary heart diseases, diabetes, cancers).

The fatty acid (C18:3n-3) is considered essential for the organism of man and animals, and must be supplied in the diet. In the organism, other PUFA n-3 (EPA, DHA) are synthesized of it by the effect of specific desaturases and elongases, which are physiologically many times more effective (Steffens 1997). The organism of fresh water fish is very well able to synthesize EPA and DHA acids from their precursors (Steffens et al. 1997). This might

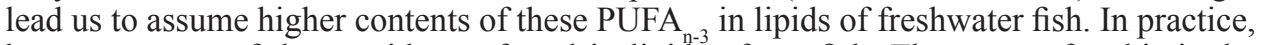
however, more of these acids are found in lipids of sea fish. The reason for this is the favourable composition of fatty acids in marine phytoplankton.

The content of $\alpha$-linolenic acid (PS $\times$ ROP: $0.86 \pm 0.09 \%$ ) and its metabolites EPA and DHA (PS $\times$ ROP: $0.69 \pm 0.09 \%$ and $0.35 \pm 0.02 \%$, respectively) in the IML of carp monitored in our experiment was very low compared with data published by other authors (Fajmonová et al. 2003; Rasoarahona et al. 2004; Komprda et al. 2005). The very low levels of these PUFA ${ }_{n-3}$ in IML of carp monitored in our study suggest that natural diet consumption was significantly reduced because the carp preferentially consumed energy-rich feed (i.e. wheat) fed to them during the vegetation season, or that the amount of that natural diet in the rearing environment was insufficient. According to Steffens et al. (1998), particularly the $\alpha$-linolenic acid is sufficiently represented in natural carp diet (zooplankton: $15.4 \%$, chironomid larvae: $15.6 \%$ ). The $\alpha$-linolenic acid uptake from wheat on the contrary is low (5.2\%), and EPA and DHA are not present in wheat at all (Steffens et al. 1998). Another reason for the low content of EPA and DHA in carp lipids might be the low activity of specific desaturases or elongases. According to Velíšek (1999), their activity might be negatively influenced mainly by the deficiency of vitamins $\mathrm{B}_{6}$ and $\mathrm{H}$ (biotin) and of mineral substances such as $\mathrm{Zn}, \mathrm{Mg}$ and $\mathrm{Ca}$.

The very low PUFA ${ }_{n-3}$ content in carp fat affected the n-6/n-3 (PS $\times$ ROP: $3.25 \pm 0.18$ ) and they did not correspond to levels recommended by Okuyama et al. (1997) for freshwater fish ( $\mathrm{n}-6 / \mathrm{n}-3$ ratio $\leq 2)$. The possibility to actively adjust $\mathrm{PUFA}_{\mathrm{n}-6}$ and $\mathrm{PUFA}_{\mathrm{n}-3}$ contents and, subsequently, their mutual ratio in carp has been experimentally investigated by Runge et al. (1987), who fed carps a diet supplemented with $12 \%$ fish or linseed oil. When their diet was supplemented with $12 \%$ fish oil, EPA and DHA levels increased to $6.7 \%$ and $6.8 \%$, respectively, while $\alpha$-linolenic acid level remained low (4\%). When their diet was supplemented with $12 \%$ linseed oil, content of $\alpha$-linolenic acid in carp fat substantially increased (32.3\%), while EPA and DHA contents were low (1\% each) (Runge et al. 1987). According to Zelenka et al. (2006) linseed oil made of common flax varieties contains ca. $14 \%$ of linoleic acid and more than $60 \%$ of $\alpha$-linolenic acid of all fatty acids (e.g. seeds of the cultivar Atalante). However, relatively recently plant breeders have selected some flax cultivars that contain more than $70 \%$ of linoleic acid and only $2 \%$ of $\alpha$-linolenic acid (Zelenka et al. 2003).

From the results of our experiments and other data above, the following conclusions can 
be drawn. The composition of fatty acids was not affected to any great extent by the hybrid type or by gender. Compared with mirror carp controls $(\mathrm{M} 2 \times \mathrm{M} 72)$ and scaly hybrids $(\mathrm{PS} \times \mathrm{M} 72)$, IML of experimental hybrids PS $\times$ ROP were found to contain significantly $(p<0.05)$ more PUFA $_{\text {sum }}$. The type of feed used (wheat) increased the content of oleic acid (PS $\times$ ROP: $54.94 \pm 0.70 \%)$ and MUFA $_{\text {sum }}(\mathrm{PS} \times \mathrm{ROP}: 64.20 \pm 0.57 \%)$ in carp fat. The diet used had negative effect on the content of $\alpha$-linolenic acid (PS $\times$ ROP: $0.86 \pm 0.09 \%$ ), EPA (PS $\times$ ROP: $0.69 \pm 0.09 \%$ ) and DHA (PS $\times$ ROP: $0.35 \pm 0.02 \%$ ) and, consequently, also on n-6/n-3 (PS $\times$ ROP: $3.25 \pm 0.18$ ) PUFA ratio. From this point of view, the IML of the carp groups studied constituted a relatively minor source of PUFA $_{n-3}(P S \times R O P: 2.39 \pm 0.09 \%)$. On the basis of our findings, we recommend to supplement carp diets with linseed oil made of seeds of the cultivar e.g. Atalante. That should increase PUFA ${ }_{n-3}$ content in carp fat, reduce the n-6/n-3 ratio and increase the n-3/n-6 PUFA ratio. In that case, the fast-growing experimental hybrid carp PS $\times$ ROP might be very attractive also from human nutrition point of view.

\section{Složení mastných kyselin v intramuskulárních lipidech 3letých experimentálních šupinatých hybridů kapra obecného (Cyprinus carpio)}

Cílem práce bylo stanovení rozdílů ve složení mastných kyselin, jejich celkového množství a podílu (n-6/n-3) v intramuskulárních lipidech (IML) experimentálních šupinatých skupin kapra (čistá linie PŠ: přerovský šupinatý kapr, hybrid PŠ $\times$ M72: přerovský šupinatý kapr $\times$ severský lysý kapr, hybrid PŠ x ROP: přerovský šupinatý kapr × ropšínský šupinatý kapr) ve srovnání s lysou kontrolou (hybrid M2 × M72: mad’arský lysec × severský lysý kapr). Obsah tuku v mase experimentálních skupin kaprů (PŠ, PŠ $\times$ M72, PŠ $\times$ ROP) ve srovnání s kontrolou $(\mathrm{M} 2 \times \mathrm{M} 72)$ byl prakticky stejný $(p>0.05)$. Nejvyšší hodnota tuku byla zjištěna $\mathrm{v}$ mase hybrida PŠ $\times$ ROP $\left(89.8 \pm 1.94 \mathrm{~g} \cdot \mathrm{kg}^{-1}\right)$. Složení mastných kyselin v IML nebylo druhem hybrida nebo pohlavím výrazněji ovlivněno. Pouze v IML hybrida PŠ $\times$ ROP bylo zjištěno ve srovnání s kontrolou $(\mathrm{M} 2 \times \mathrm{M} 72)$ a hybridem $(\mathrm{P} \breve{S} \times \mathrm{M} 72)$ průkazně $(p<0.05)$ více polynenasycených mastných kyselin PUFA $_{\text {sum }}$. Vyšší zastoupení kyseliny olejové (PS̆ $\times$ ROP: $54.94 \pm 0.70 \%$ ) v tuku kaprů se projevilo zvýšeným obsahem mononenasycených mastných kyselin MUFA $(\mathrm{PS} \times$ ROP: $64.20 \pm 0.57 \%$ ). IML hybrida PŠ $\times$ ROP obsahovaly $6.99 \pm 0.20 \%$ kyseliny linolové a $0.53 \pm 0.02 \%$ kyseliny arachidonové. Obsah kyseliny $\alpha-$ linolenové (PŠ $\times$ ROP: $0.86 \pm 0.09 \%$ ), eikosapentaenové (EPA) (PŠ $\times$ ROP: $0.69 \pm 0.09 \%$ ) a dokosahexaenové (DHA) (PŠ $\times$ ROP: $0.35 \pm 0.02 \%$ ) byl nízký a ovlivnil podíl PUFA n-6/n-3 (PŠ $\times$ ROP: $3.25 \pm 0.18$ ). IML kaprů z tohoto experimentu můžeme považovat za méně významný zdroj PUFA $_{\mathrm{n}-3}(\mathrm{PS} \times \mathrm{ROP}: 2.39 \pm 0.09 \%)$.

\section{Acknowledgement}

This experimental study was supported by the Ministry of Education, Youth and Sports of the Czech Republic (Research Plan MSM6215712402).

The authors are also grateful to all the staff of Rybníkářství Pohořelice Comp. for their kind help in processing the fish and their overall technical assistance.

\section{References}

ANONYMOUS 1994: Fats and Oils in Human Nutrition: Report of a joint expert consultation. FAO Food and Nutrition Paper No. 57

BUCHTOVÁ H, SVOBODOVÁ Z, KOCOUR M, VELÍŠEK J 2006a: Evaluation of growth and dressing out parameters of experimental scaly crossbreds in three-year-old common carp (Cyprinus carpio, Linnaeus 1758). Aquac Res 37: 466-471

BUCHTOVÁ H, SVOBODOVÁ Z, KOCOUR M, VELÍŠEK J 2006b: Evaluation of the dressing percentage of three-year-old experimental scaly crossbreds of the common carp (Cyprinus carpio, Linnaeus 1758) in relation to sex. Acta Vet Brno 75: 123-132

BUCHTOVÁ H, SVOBODOVÁ Z, KOCOUR M, VELÍŠEK J 2007: Amino acid composition of edible parts of threeyear-old experimental scaly crossbreds of common carp (Cyprinus carpio, Linnaeus 1758). Aquac Res 38: 625-634 
COLETTE K 2001: Dietary fat and cardiovascular disease. London: British Nutrition Foundation 21

CSENGERI I 1996: Dietary effects on fatty acid metabolism of common carp. Arch Anim Nutr 49: 73-92

CSENGERI I, FARKAS T, MAJOROS F, OLÁH J, SZALAY M 1978: Effect of feeds on the fatty acid composition of carp (Cyprinus carpio L.). Aquacult Hung 1: 35-43

FAJMONOVÁ E, ZELENKA J, KOMPRDA T, KLADROBA D, ŠARMANOVÁ I 2003: Effect of sex, growth intensity and heat treatment on fatty acid composition of common carp (Cyprinus carpio) fillets. Czech J Anim Sci 48: 85-92

GERI G, POLI B, GUALTIERI M, LUPI P, PARISI G 1995: Body traits and chemical composition of muscle in the common carp (Cyprinus carpio L.) as influenced by age and rearing environment. Aquaculture 129: 329-333

HENDERSON RJ 1996: Fatty acid metabolism in freshwater fish with particular reference to polyunsaturated fatty acids. Arch Tierernähr 49: 5-22

KOMPRDA T, ZELENKA J, FAJMONOVÁ E, FIALOVÁ M, KLADROBA D 2005: Arachidonic acid and longchain n-3 polyunsaturated fatty acid contents in meat of selected poultry and fish species in relation to dietary fat sources. J Agric Food Chem 53: 6804-6812

LINHART O, GELA D, RODINA M, ŠLECHTOVÁ V, ŠLECHTA V 2002: Top-crossing with paternal inheritance testing of common carp (Cyprinus carpio L.) progeny under two altitude conditions. Aquaculture 204: 481491

OKUYAMA H, KOBAYASHI T, WATANABE S 1997: Dietary fatty acids-the n-6/n-3 balance and chronic elderly diseases. Excess linoleic acid and relative n-3 deficiency syndrome seen in Japan. Prog Lipid Res 35: 409-457

RASOARAHONA JRE, BARNATHAN G, BIANCHINI JP, GAYDOU E 2004: Annual Evolution of fatty acid profile from muscle lipids of the common carp (Cyprinus carpio) in Madagascar inland waters. J Agric Food Chem 52: 7339-7344

RUNGE G, STEINHART H, SCHWARZ FJ, KIRCHGEBNER M 1987: Influence of different fats with varing addition of $\alpha$-tocopherol acetate on the fatty acid composition of carp (Cyprinus carpio L.). Fat Sci Technol 89: 389-393

STEFFENS W 1997: Effects of variation in essential fatty acids in fish feeds on nutritive value of freshwater fish for humans. Aquaculture 151: 97-119

STEFFENS W, WIRTH M, FÜLLNER G 1998: Fatty acid composition of tench (Tinca tinca L.) under different nutritional conditions. Pol Arch Hydrobiol 45 (Suppl): 353-359

VELÍŠEK J 1999: Food chemical (in Czech). OSSIS Tábor, pp. 3-72

ZELENKA J, FAJMONOVÁ E, KOMPRDA T, KLADROBA D, ŠARMANOVÁ I 2003: Effect of dietary linseed and sunflower oil on cholesterol and fatty acid contents in rainbow trout (Oncorhynchus mykiss) fillets. Czech J Anim Sci 48: 321-330

ZELENKA J, SCHNEIDEROVÁ D, MRKVICOVÁ E 2006: Linseed oils with different fatty acid patterns in the diet of broiler chickens. Czech J Anim Sci 51: 117-121 